\section{Performance ANALYsis FuZzY-PID VERSUS FUZZY FOR QUADCOPTER ALTITUDE LOCK SYSTEM}

\author{
Hendi Wicaksono*, Yohanes Gunawan, Arbil Yodinata, Leonardie \\ University of Surabaya, East Java, Indonesia
}

Article history

Received

27 April 2015

Received in revised form

15 June 2015

Accepted

25 November 2015

*Corresponding author

hendi@ubaya.ac.id
Graphical abstract

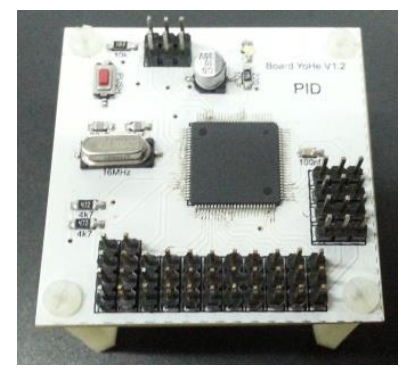

\begin{abstract}
Mostly quadcopter has a flight controller to receive signal from remote control to control four brushless motor speed. In this paper, the researchers introduced a new control method to make quadcopter altitude lock system using Fuzzy-PID and perform a comparative performance analysis between the Fuzzy controller and the new Fuzzy-PID controller. Fuzzy controller has ability to solve uncertainty within the system, by incorporating with altitude sensor data. On the other hand, Fuzzy-PID has the ability to gain the target level with $\mathrm{Kp}, \mathrm{Ki}, \mathrm{Kd}$ values controlled. In this paper the researchers present an analysis to compare the control method between Fuzzy and Fuzzy-PID with regards to the stability altitude lock system. The stability of the altitude lock system can be measured by how small the oscillations occurred. Fuzzy control has shown to produce better result than Fuzzy-PID control. Fuzzy control has $14 \mathrm{~cm}$ as its average oscillation, while Fuzzy-PID recorded $24 \mathrm{~cm}$ as its average oscillation.
\end{abstract}

Keywords: Quadcopter altitude lock system, Fuzzy, Fuzzy-PID controller, YoHe board

(c) 2015 Penerbit UTM Press. All rights reserved

\subsection{INTRODUCTION}

The quadcopter concept has existed many years ago. The first quadcopter were developed by George DeBothezat and Etienne Oemichen in 1922 was powered by simple controllers. The most popular flight controller today is the KK2.0 which have autonomous attitude control only, but not the autonomous altitude control yet. The autonomous altitude control is important for imaging application [1]. Altitude stability is needed to obtain focused image captured and quadcopter altitude lock system had been developed using several control methods. The researchers started a study using PID controller [2], Fuzzy controller [3], T2-Fuzzy controller [4] in the quadcopter. The researchers designed and implemented a control method in a real time using the YoHe board which contained ATMega2560 AVR microcontroller to control a quadcopter which is symmetrically designed with four similar sized rotor and four equal length rods [5]. Quadcopter research has been growing fast in the last few decades because quadcopters can be used for many applications. Quadcopter can be categorized as a helicopter which has a Vertical Take Off and Landing (VTOL) system which has many advantages over other flying principles including airplane flying method [6]. With the VTOL system, a quadcopter can fly omnidirectionally with additional ability to fly in hover conditions. All movements can be controlled by given a varying speed to the rotors where each rotor produces different torque and thrust. With varying speed of the four rotors, a quadcopter has three motions, i.e. pitch motion, yaw motion, and roll motion [7].

Minimum components a quadcopter should have include 4 units of propellers, 4 units of brushless motor DC (BLDC), 4 unit of Electronic Speed Controller (ESC), accelerometer sensor and gyroscope sensor [5], [8], 
[9]. In a quadcopter, the front and rear rotors rotate clockwise, while the left and right rotors rotate counter-clockwise. Vertical motion is controlled by the throttle input, where the sum of the thrusts of each motors are presented in Figure 1 [7].

Studies on quadcopter modeling and control had increased rapidly in recent years. Examples of some studies are as follows: developments of flying robots includeing dynamic modeling, vehicle design optimization and control, new controller to improve the ability to control the orientation angles [6], low cost development of an autonomous hover for quadcopter [10], design and control of quadrotor prototype with 3-axis accelerometer and compass as its sensors, introduction of the Kalman filter, sensors and motors dynamics in the control loop [11], a simpler method for segmentation and horizon detection based on polarization, the catadioptric sensors used, and a comprehensive review on attitude estimation approaches from visual sensors [12]. In the development of hybrid controller, the researchers believed that the control performance of the Fuzzy PD controller was slightly better then the classical PD controller in simulations and experiments, as the biggest advantage of the hybrid fuzzy PD controller is the robustness against noise, and its ease for implementation [13]. The development of an adaptive hybrid Fuzzy Logic based PID (FPID) algorithm for attitude stabilizing flight control system is successfully simulated using MATLAB Simulink [14].

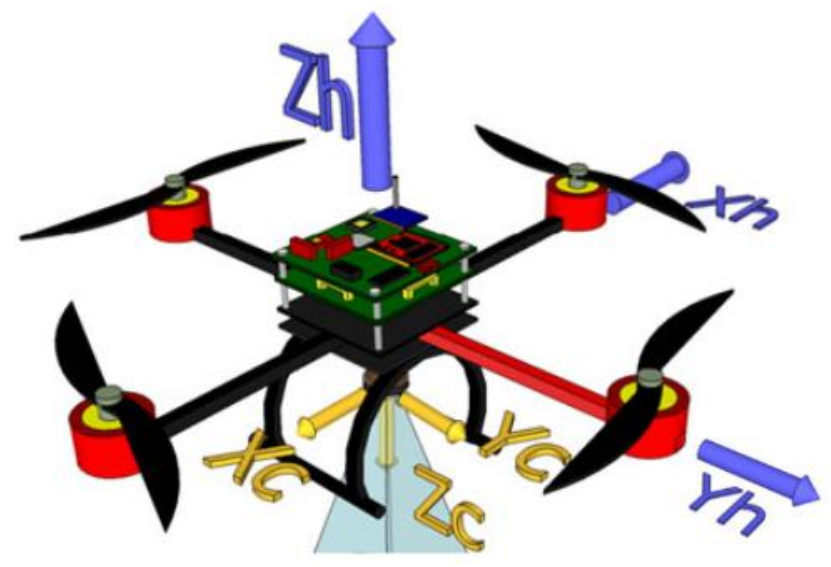

Figure 1 Visual system of quadcopter [7]

A Fuzzy control method in the last few decades was implemented upon various systems which have different uncertainty levels. Some examples of these Fuzzy studies can be summarized as follows: optimized fuzzy logic controller using the Fuzzy Logic Toolbox and Simulink to control an inverted pendulum system [15], a modular fuzzy logic for the autonomous control of quadrotors in general, without the need for a precise mathematical model of their complex and ill-defined dynamics [16] as well as modeling and tye hybrid Fuzzy PD control of a four-rotor helicopter [13].
The basic form of Fuzzy-PID is the PID controller. In an industrial control processes, PID control is mostly used because of their simple structure and robustness for wide range of operation conditions [17]. The PID design needs specification for three parameters such as proportional gain, integral gain, and derivative gain [17]. The problem was solved using Fuzzy for control gain scheduling whereby the PID parameters can be determined on-line based on errors and their derivative [17].

The body of the paper is organized into 6 sections. Section 2 describes quadcopter system that used in this paper. The Fuzzy and Fuzzy-PID theory and control strategy is given in section 3 and section 4 . Section 5 describes the experimental results and finally the summary are given in section 6 .

\subsection{QUADCOPTER SYSTEM}

Figure 2 shows the complete quadcopter system. A YoHe board based on AVR ATMega 2560 was chosen as an onboard microcontroller with $256 \mathrm{~Kb}$ memory as shown on Figure 3.

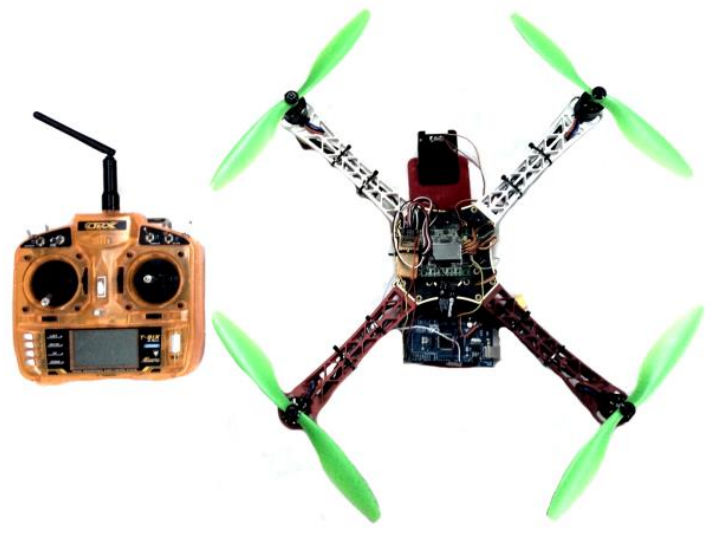

Figure 2 Quadcopter system

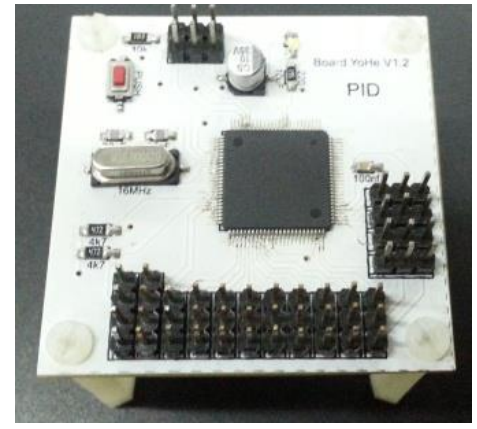

Figure 3 YoHe board

In this paper, quadcopter used a frame with $X$ copter models like seen in Figure 2. This quadcopter comes completed with a propeller, motor brushes, Electronic Speed Controller (ESC), flight controller 
KK2.0. Quadcopter parts in Figure 4 and parts specification seen on Table 1.

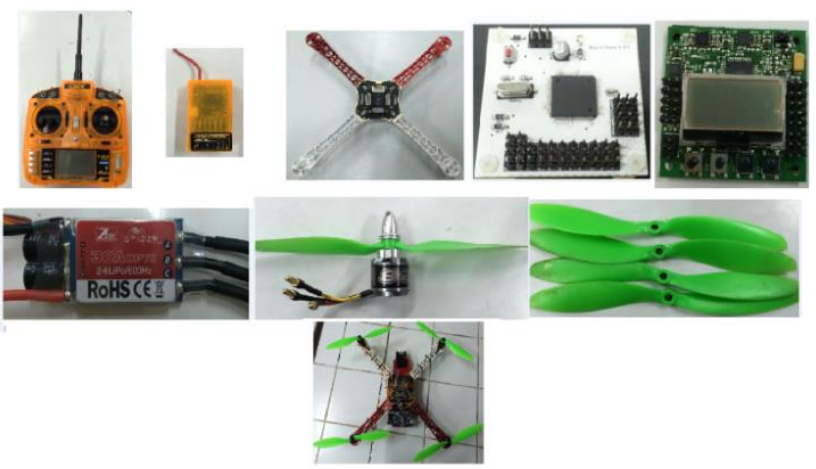

Figure 4 Quadcopter main parts

Table 1 Quadcopter parts specification

\begin{tabular}{|c|c|c|c|c|}
\hline No & Part & Total & Merk & Specs \\
\hline 1 & X-Copter Frame & 1 & $\begin{array}{c}\text { Whirlwind } \\
\text { FY450 }\end{array}$ & $280 \mathrm{~g}$ \\
\hline 2 & Propeller & $\begin{array}{c}2 \mathrm{CW}, \\
\text { 2CCW }\end{array}$ & Dji 10x4.7 & Plastic \\
\hline 3 & Brushless Motor & 4 & $\begin{array}{c}\text { NTM Prop } \\
\text { Drive }\end{array}$ & $1000 \mathrm{KV}$ \\
\hline 4 & ESC & 4 & ZTW Spider & $30 \mathrm{~A}$ \\
\hline 5 & Flight Controller & 1 & KK2.0 & \\
\hline 6 & Battery & 1 & Li-Po 3 cell & $2.2 \mathrm{~A}$ \\
\hline
\end{tabular}

Figure 5 shows the wiring for normal quadcopter components, while Figure 6 shows the changed wiring with YoHe board added. Normally, four channel signal from the receiver channel can be received by KK2.0. The four channels are aileron, elevator, throttle and rudder channel. KK2.0 with PID inside as a remote signal, can give a varying PWM signal to ESC which then makes motor speed. In contrast, as shown on Figure 6, only three channel from the receiver channel can be directly connected to KK2.0. One channel is the throttle channel which moves the connection to the YoHe board and from from the YoHe board there is one channel which is connected to KK2.0. For the altitude detection, SRF05 ultrasonic I used in this quadcopter. Figure 7 is the wiring outcome in physically form.

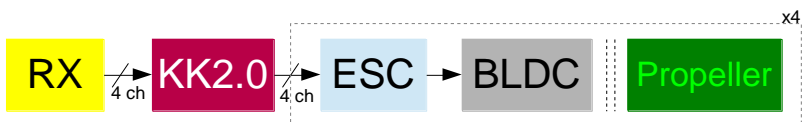

Figure 5 Normally quadcopter components wiring

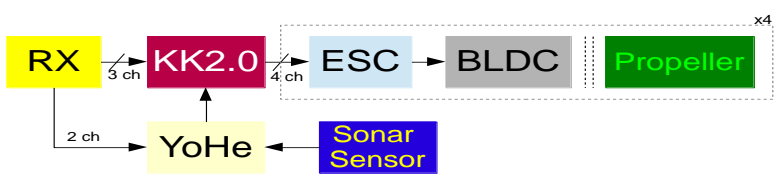

Figure 6 Quadcopter wiring with altitude lock system

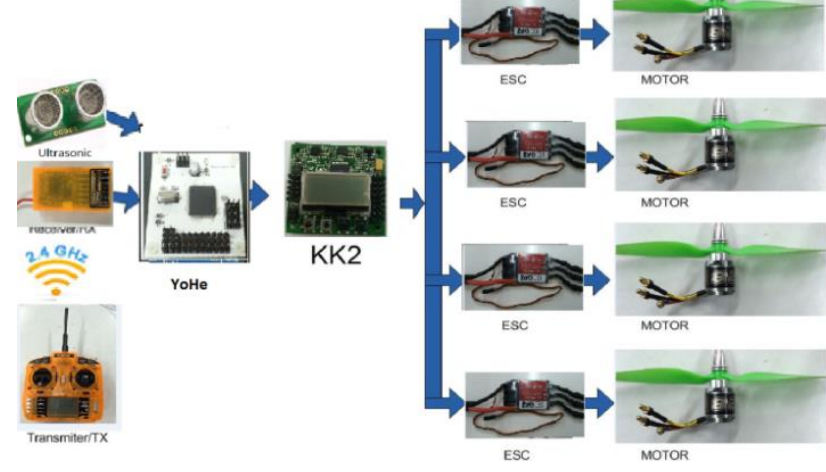

Figure 7 Quadcopter wiring in physically form

\subsection{FUZZY and FUZZY-PID DESIGN}

In the first step of design, Fuzzy control is designed to get the range of Input Membership Function (IMF) and Output Membership Function (OMF). Subsequently, Fuzzy-PID was designed to follow the IMF and OMF of Fuzzy control design. Figure 8 shows the structure of Fuzzy control design with Error and dError (Error(n)Error(n-1)) as the two inputs and throttle as the sole output.

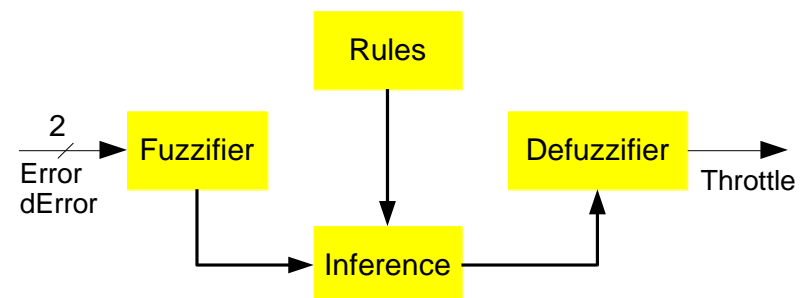

Figure 8 Structure of altitude lock fuzzy design

Figure 9 presents an overview on the Fuzzy control process. The Fuzzy control has two inputs and one output, i.e. Error and Delta Error (dError) as inputs, and throttle as output. Error is defined as height(n) - height (desired), while dError is defined as Error(n) - $\operatorname{Error}(n-1)$. If a system is designed with three IMF for Error label and also three IMF for dError label, the Error Membership Function will have three linguistic variables, i.e. NE (Negative Error), ZE (Zero Error) and PE (Positive Error) with values as shown in Figure 10. 


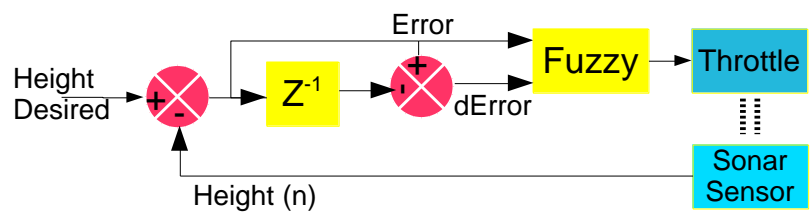

Figure 9 Fuzzy control process

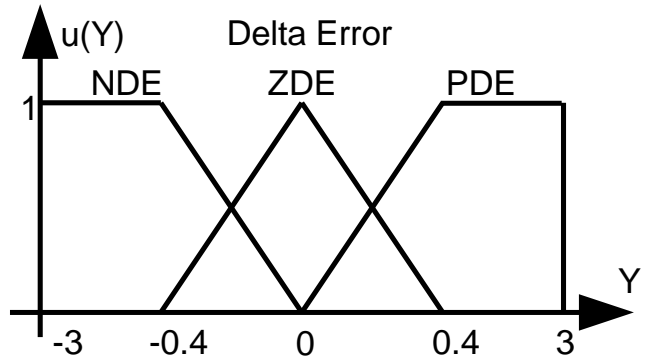

Figure 10 Error membership function for fuzzy control

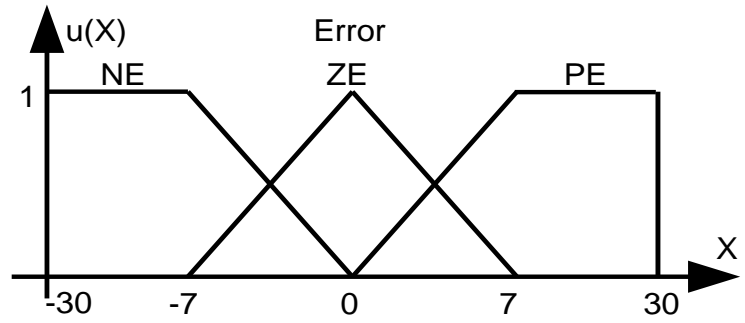

Figure 11 Delta error membership function for fuzzy control

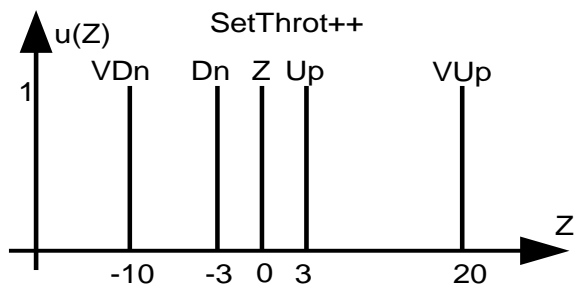

Figure 12 Throttle membership function for fuzzy control

DError Membership Function also has three linguistic variables, i.e. NDE (Negative Delta Error), ZDE (Zero Delta Error), and PDE (Positive Delta Error) as shown in Figure 11. The output, throttle has a Membership Function models which are different where Trapezoid fuzzy sets are used for IMF, and singleton fuzzy sets are used for OMF. The model based on singleton fuzzy sets used for OMF is shown in Figure 12
The next step is to decide the fuzzy rules in inference step for three Error IMFs and three DError IMFs whereby the setup has nine rules as follows:

- If Error is NE and Delta Error is NDE, then Throttle is VUp

- If Error is NE and Delta Error is ZDE, then Throttle is VUP

- If Error is NE and Delta Error is PDE, then Throttle is Up

- If Error is ZE and Delta Error is NDE, then Throttle is Up

- If Error is ZE and Delta Error is ZDE, then Throttle is Zero

- If Error is ZE and Delta Error is PDE then Throttle is Dn

- If Error is PE and Delta Error is NDE, then Throttle is doing

- If Error is PE and Delta Error is ZDE. then Throttle is VDn

- If Error is PE and Delta Error is PDE, then Throttle is VDn

A summary of the Fuzzy rules is shown in Table 2.

Table 2 Fuzzy rule inference

\begin{tabular}{|c|c|c|c|c|}
\hline \multicolumn{2}{|c|}{} & \multicolumn{3}{c|}{ Delta Error } \\
\cline { 3 - 5 } \multicolumn{2}{|c|}{} & NDE & ZDE & PDE \\
\hline \multirow{3}{*}{ ERROR } & NE & Vup & Vup & Up \\
\cline { 2 - 5 } & ZE & Up & Zero & Dn \\
\cline { 2 - 5 } & PE & Dn & VDn & VDn \\
\hline
\end{tabular}

Many methods can be used in the defuzzification step of which the Center of Area (COA) method was used in this research based on the following formula:

$$
\mathrm{COA}=(X * u(X))+(Y * u(Y))+(Z * u(Z)) /(X+Y+Z)
$$

All parameters of Fuzzy included IMF range values and OMF range values as explained earlier was optimized many times until got that final range value.

Next, Fuzzy-PID was designed by Fuzzy design and its parameters as reference. PID control only has one input and one output as seen in . Error as an input, and throttle as an output. There are three parameters for PID control, i.e. Kp (proportional gain), Ki (integral gain), and $\mathrm{Kd}$ (derivative gain). in this experiment, the researchers used Fuzzy control for tuning/scheduling which needs $\mathrm{Kp}, \mathrm{Ki}$, and $\mathrm{Kd}$ prediction range values. The structure of control process of Fuzzy-PID is shown in Figure 14.

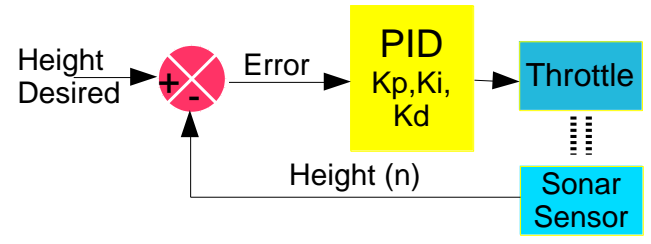

Figure 13 PID control process 


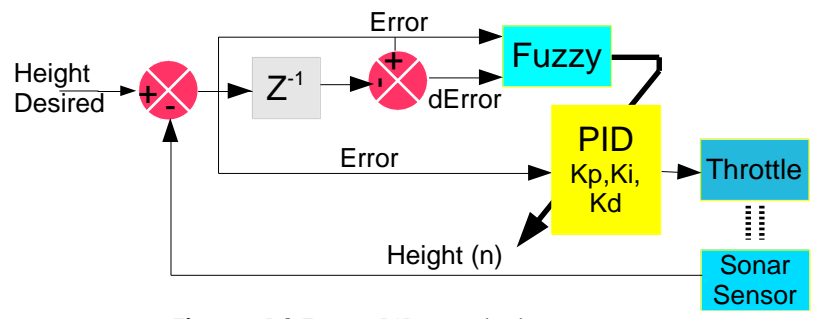

Figure 14 Fuzzy-PID control process

Like any Fuzzy design, this Fuzzy-PID needs IMF and OMF. The Fuzzy control in Fuzzy-PID has a task to handle/tune $\Delta \mathrm{Kp}, \Delta \mathrm{Ki}$, and $\Delta \mathrm{Kd}$ which means this Fuzzy of Fuzzy-PID has two inputs, i.e. Error and dError, and also three outputs, i.e. $\Delta \mathrm{Kp}, \Delta \mathrm{Ki}$, and $\Delta \mathrm{Kd}$. The linguistic variable of Error Membership Function for Fuzzy-PID is shown in Figure 15 is the same with the Fuzzy Control. The delta error shown in Figure 16 is also the same as with the Fuzzy control.

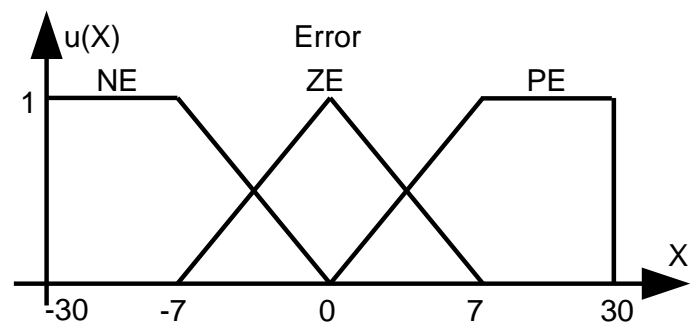

Figure 15 Error IMF for fuzzy-PID control

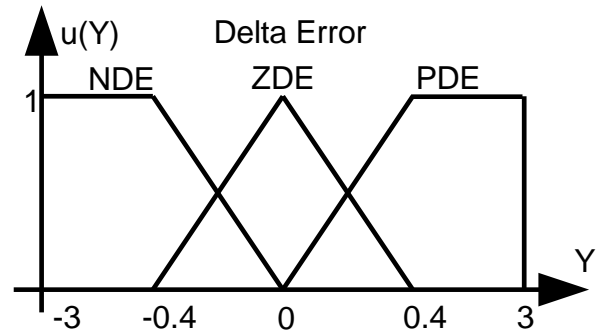

Figure 16 Delta error IMF for fuzzy-PID control

The difference between Fuzzy control and FuzzyPID control is in the OMF linguistic variable. Fuzzy-PID has three outputs as shown in Figure 17.

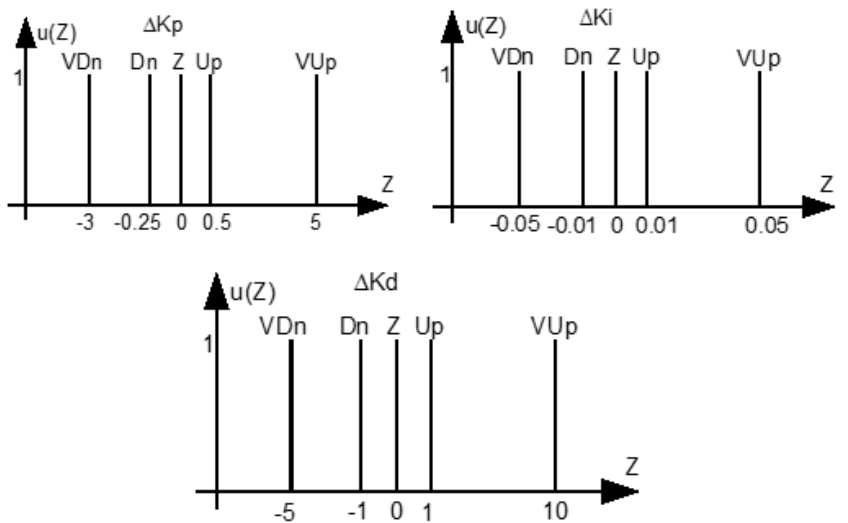

Figure 17 Three OMF fuzzy-PID

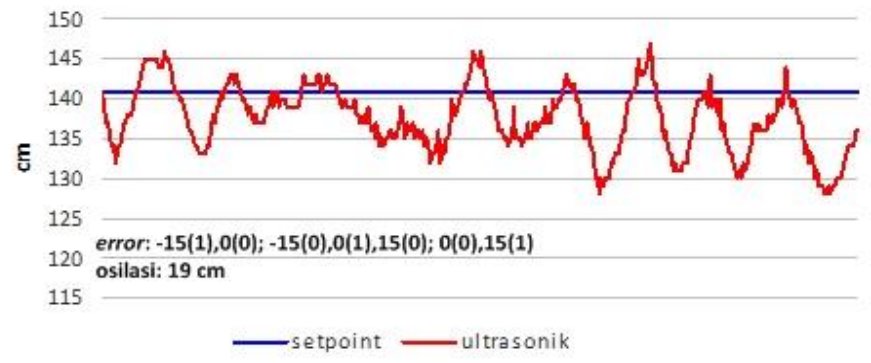

Figure 18 Result \# 1 of Fuzzy Control with $19 \mathrm{~cm}$ Oscillation

\subsection{RESULT AND DISCUSSIONS}

The fuzzy control results can be seen in and 19 while FuzzyPID control results are shown in

andFigure 21. In this paper, the researchers have shown only the two best results after doing many trial and error experiments to get the best performance. The altitude lock is activated around $100 \mathrm{~cm}$ and the data was sent to the computer via Bluetooth $\vee 3$.

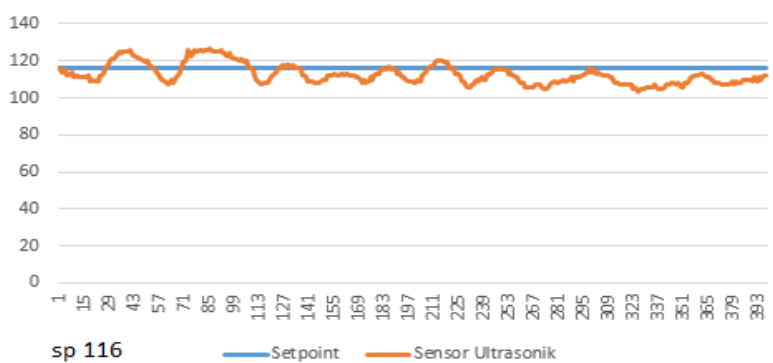

Figure 19 Result \#2 Fuzzy control with $14 \mathrm{~cm}$ oscillation 


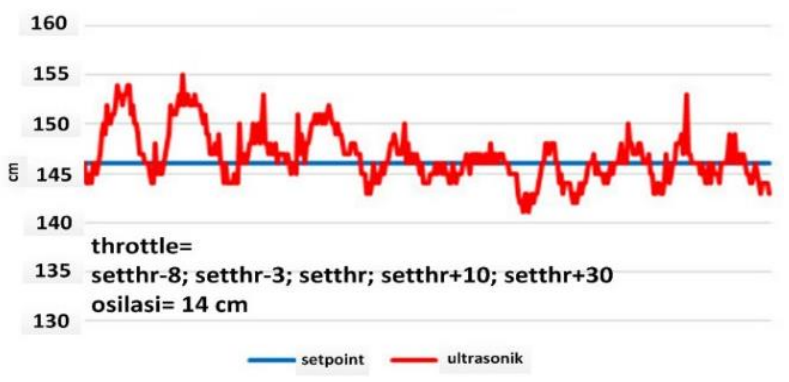

Figure 20 Result \# 1 Fuzzy-PID control with $27 \mathrm{~cm}$ oscillation

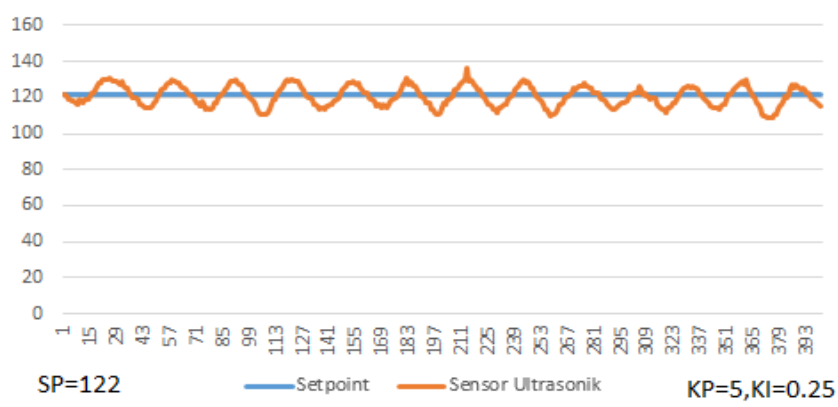

Figure 21 Result \#2 fuzzy-PID control with $24 \mathrm{~cm}$ oscillation

\subsection{CONCLUSION}

In this paper, Fuzzy control and Fuzzy-PID control was successfully designed and real-time implemented based on AVR microcontroller on-board yeah. Although Fuzzy-PID has a fuzzy system, but the main controller still PID control. Comparison between Fuzzy and Fuzzy-PID control on how big an oscillation happened. The best result of Fuzzy controller is $14 \mathrm{~cm}$ in its oscillation, while Fuzzy-PID only reach a minimum oscillation is $24 \mathrm{~cm}$. In Figure 22 shown variations of $\mathrm{Kp}$ which involved self-tuning of Fuzzy in the Fuzzy-PID system.

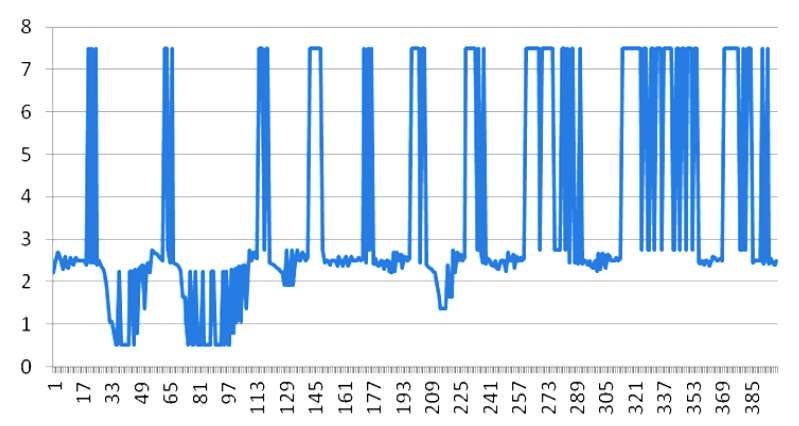

- KP

Figure $22 \mathrm{KP}$ Changed by fuzzy in fuzzy-PID system

\section{Acknowledgement}

We are grateful for the Dikti Indonesia Research Grant to Author 1 and Author 2.

\section{References}

[1] B. T. M. Leong, S. M. Low, and M. P.-L. 2012. Ooi, Low-Cost Microcontroller-based Hover Control Design of a Quadcopter. Procedia Eng. 41:458-464.

[2] H. Irawan, Y. G. Yusuf, and H. Wicaksono. 2014. Pengunci Ketinggian Pada QuadCopter Berbasis Kontroler PID Menggunakan Sensor Ultrasonik, in Digital Information \& System Conference.

[3] A. Yodinata, Y. Yusuf, and H. Wicaksono. 2014. Hold Altitude Design for QuadCopter Using Barometric BMP085 Based on Fuzzy Controller. in Digital Information \& System Conference.

[4] C. Kristanto, Y. G. Yusuf, H. Wicaksono, and R. K. Surabaya. 2014. Desain Simulasi Penjaga Ketinggian QuadCopter Menggunakan T2-Fuzzy Logic Sebagai Sistem Kontrol. in Digital Information \& System Conference.

[5] P. Basta. 2012. Quad Copter Flight. California State University.

[6] S. Bouabdallah, P. Murrieri, and R. Siegwart. 2004. Design and control of an indoor micro quadrotor. IEEE Int. Conf. Robot. Autom. Proceedings. ICRA. 04(5): 4393-4398.

[7] L. R. García Carrillo, E. Rondon, a. Sanchez, a. Dzul, R. Lozano, and L. Carrillo. 2010. Stabilization and trajectory tracking of a quad-rotor using vision. J. Intell. $61(1-4)$ : 103118.

[8] J. Rought, D. Goodhew, J. Sullivan, and A. Rodriguez. 2010. Self-Stabilizing Quad-Rotor Helicopter. no. 2.

[9] L. Burkamshaw. 2010. Towards A Low-Cost Quadrotor Research Platform. Naval PostGraduate School.

[10] C. Canetta and J. Chin. 2007. Quad-Rotor Unmanned Aerial Vehicle. Columbia University,.

[11] J. Domingues. 2009. Quadrotor prototype, Inst. Super. Tec.

[12] A. El, R. Shabayek, C. Demonceaux, O. Morel, and D. Fofi. 2011. Vision Based UAV Attitude Estimation: Progress and Insights. 1-20.

[13] B. Erginer and E. Altuğ, 2012. Design and implementation of a hybrid fuzzy logic controller for a quadrotor VTOL vehicle. Int. J. Control. Autom. Syst. 10(1):61-70.

[14] H. Desa. 2013. Adaptive Hybrid Control Algorithm Design for Attitude Stabilization of Quadrotor ( UAV ). Arch. Des Sci. 66(2): 51-64.

[15] M.I. H. Nour, J. Ooi, and K. Y. Chan, 2007. Fuzzy logic control vs. conventional PID control of an inverted pendulum robot. 2007 Int. Conf. Intell. Adv. Syst. 209-214,

[16] K. C. Vijaykumar Sureshkumar. 2014. Intelligent Fuzzy Flight Control of an Autonomous. AIAA SciTech. January: 1-10.

[17] M. Tomizuka and S. Isaka. 1993. Fuzzy Gain Scheduling of PID Controllers. IEEE Trans. Syst. Man. Cybern. 23(5): 13921398. 


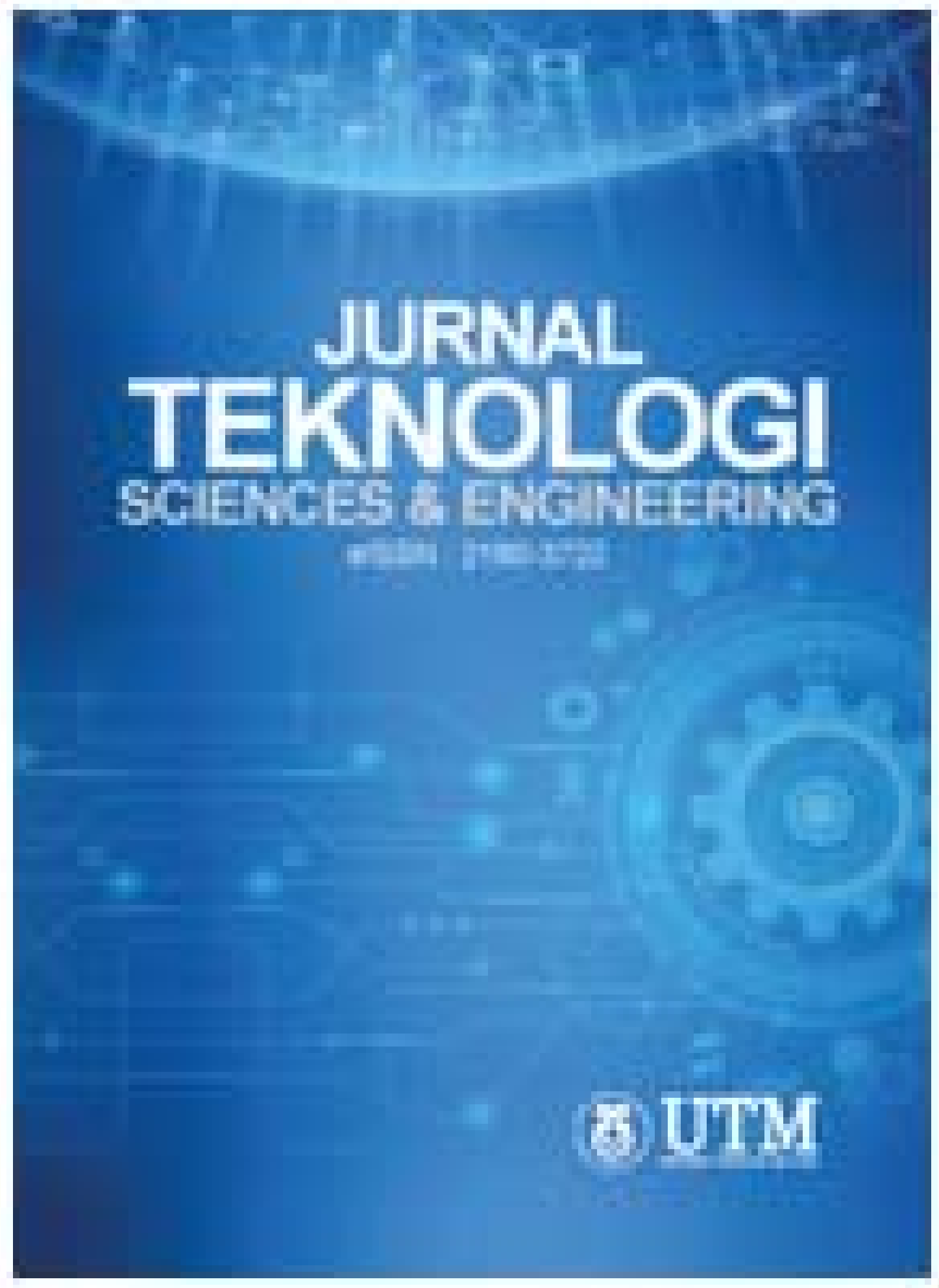




\section{Jurnal Teknologi (Sciences and Engineering) $\curvearrowright$}

\author{
COUNTRY \\ Malaysia \\ Universities and researc
}

PUBLICATION TYPE

Journals

\section{SUBJECT AREA AND CATEGORY}

Engineering

Engineering (miscellaneous)

ISSN

01279696,21803722
PUBUSHER

Penerbit Universiti Teknologi Malaysia University of Technology, Malaysia
in Scimago Institutions Rarkings

COVERAGE

2006-2007, 2010-2020
H-INDEX

22

INFORMATION

Homepage

How to publish in this journal

journal_utm@utm.my

OPEN

\section{SCOPE}

Jurnal Teknologi (Sciences \& Engineering) is an international research journal and invites contributions of original and novel fundamental research. The journal aims to provide an international forum for the presentation of original fundamental research, interpretative reviews and discussion of new developments in $\bar{A}$ in the area of Mathematics, Natural Sciences and Applied Mathematics and Natural Sciences. Papers which describe novel theory and its application to practice are welcome, as are those which illustrate the transfer of multi-disciplinary techniques from other disciplines. Reports of carefully executed experimental work, which is soundly interpreted are also welcome. The overall focus is on original and rigorous research results which have generic significance. Jurnal Teknologi (Sciences \& Engineering) invites manuscripts based on original research in any areaÅ of Mathematics, Natural Sciences (Biological Sciences, Physical Sciences: Physics, Chemistry, Astonomy, Earth Science) and Applied Mathematics and Natural Sciences (Building Physics, Mechanical Engineering, Chemical Engineering, Civil Engineering. Material Science, Bioechnology, Medical Engineering). Jurnal Teknologi (Sciences \& Engineering) does not limit itself to a single perspective or approach, but seeks to represent the diversity of the aforementioned field. Comments and Proposals: Jurnal Teknologi (Sciences \& Engineering) is interested in receiving comments/feedback on this and our other journals and welcome publication proposals for books, electronic products, new journals and co-operation for existing journals.

Q Join the conversation about this journal

Scopus Indexed Journal

Call for Papers August Issue 


\section{Scopus Indexed Journal}

Call for Papers August Issue

Fast Track Peer Roviewed Publication

FIND SIMILAR JOURNALS 3

DYNA (Colombia)

$<\mathrm{COL}$

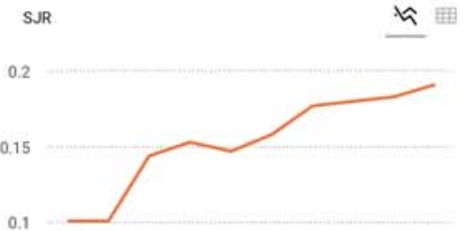

$\begin{array}{lllll}2011 & 2013 & 2015 & 2017 & 2019\end{array}$

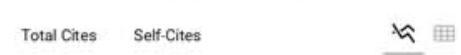

$1.5 \mathrm{k}$

750

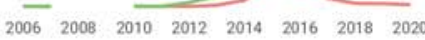

\$ International Collaboration

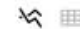

40

20

$\begin{array}{llllllll}2006 & 2008 & 2010 & 2012 & 2014 & 2016 & 2018 & 2020\end{array}$

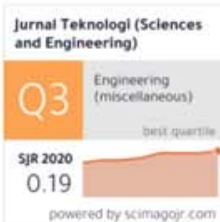

- Show this widget in your own website

Just copy the code below and paste within your htm code:

<a href="https://wwessim
Malaysian Journal of Analytical Sciences

MYS
Periodica Polytechnica: Chemical Engineering HUN

\section{$44 \%$}

similarity

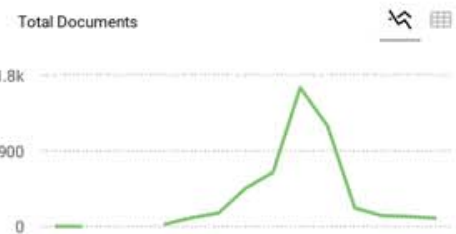

$\begin{array}{llllllll}2006 & 2008 & 2010 & 2012 & 2014 & 2016 & 2018 & 2020\end{array}$ External Cites per Doc Cites per Doc 证 0.8

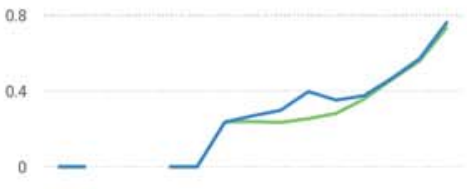

$\begin{array}{llllllll}2006 & 2008 & 2010 & 2012 & 2014 & 2016 & 2018 & 2020\end{array}$

Citable documents Non-citable documents th

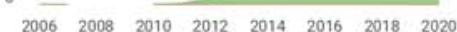

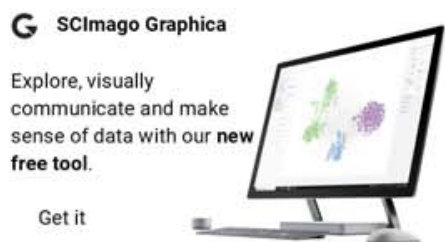

Research Journal of Chemistry and Environment IND

$43 \%$
similarity options :

Chiang Mai Journal of Science THA

\section{$43 \%$}




\section{(3) UTM JURNAL TEKNOLOGI}

\section{About the Journal}

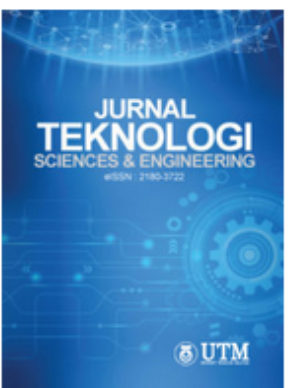

\section{SCOPE OF PUBLICATION}

Jurnal Teknologi welcomes quality research in the area of Mathematics, Natural Sciences (Biological Sciences, Physical Sciences: Physics, Chemistry, Astonomy, Earth Science) and Applied Mathematics and Natural Sciences (Building Physics, Mechanical Engineering, Chemical Engineering, Civil Engineering, Material Science, Bioechnology, Medical Engineering),

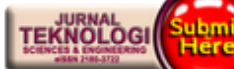

Jurnal Teknologi (Sciences and Engineering)

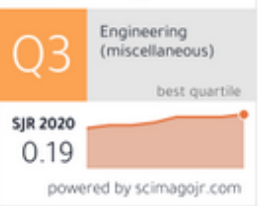

1.3 CiteScore 45n percentile
Powered by Scopus

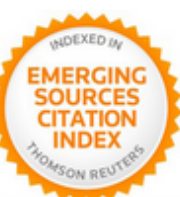




\section{Editorial Team}

\section{Chief Editor}

Professor Dr. Rosli Md Illias, Universiti Teknologi Malaysis, Malaysis

\section{Editors}

Professor Datuk. Dr. Ahmad Fauzi Ismail, Universiti Teknologi Malaysia, Malaysia Professor Dr. Muhammad Hisyam Lee, Universiti Teknologi Malaysis, Malaysia Professor Dr. Ruzairi Abdul Rahim, Universiti Teknologi Malaysia, Malaysia Professor Dr. Hadi Nur, Universiti Teknologi Malaysia, Malaysia Professor Dr. Mohammad Nazri Mohd. Jasfar, Universiti Teknologi Malaysia, Malaysia Professor Dr. Safian Sharif, Universiti Teknologi Malaysia, Malaysia Professor Sr. Gs Dr. Mazlan Hashim, Universiti Teknologi Malaysia, Malaysia Professor Dr. Hesham Ali El-Enshasy, Universiti Teknologi Malaysis, Malaysia Prof. Dr. Norhazilan Md Noor, Universiti Teknologi Malaysis, Malaysia, Malaysia Assoc. Prof. Dr. Mohd Hafiz Dzarfan Othman, Universiti Teknologi Malaysia, Malaysia Assoc. Prof. Ts. Dr. Goh Pei Sean, Universiti Teknologi Malaysia, Malaysia Dr. Syafiqah Saidin, Universiti Teknologi Malaysia, Malaysia Assoc. Prof. Ts. Dr. Dalila Mat Said, Universiti Teknologi Malaysis, Malaysia Professor Dr. Fahrul Zaman Huyop, Universiti Teknologi Malaysia, Malaysia Assoc. Professor Dr. Roswanira Ab. Wahab, Universiti Teknologi Malaysia, Malaysia

\section{Editorial Board}

Professor Craig D. Williams, University of Wolverhampton, United Kingdom

Professor I. S. Jawahir, University of Kentucky, United States

Professor Dr. Xianshe Feng, University of Waterloo, Canada

Professor Dr. Mustafizur Rahman, National University of Singapore, Singapore

Professor Dr. William MeClusky, University of Ulster, United Kingdom

Professor Vijay K. Arora, Wilkes University, United States

Professor Dr. Muhamad Riaz, King Fahd University of Petroleum \&. Minerals Dhahran, Saudi Arabia Assoc. Prof. Dr. G. Arthanareeswaran, National Institute of Technology, Tiruchirapalli, INDIA Assoc. Professor Dr. Arun M Isloor, National Institute of Technology Karnataka, INDIA Professor Dr. Jamaliah Md Jahim, Universiti Kebangsasn Malaysia, Malaysia, Malaysia Professor Dr. Che Hassan Che Haron, Universiti Kebangsaan Malaysia, Malaysia 


\section{Vol. 77 No. 22: Emerging and Current Issues In Engineering, Mathematics and Technology Disciplines Vol. 1}

Chief Editor:Amran Md.Rasli (UTM)ÂA Editorial Boards:ÂA Ayuba A Aminu (University of Maiduguri, Borno State. Nigeria), A Aqeel Ahmed (Lahore Leads University

Pakistan), Â Ashfaq Ahmed (University of Sargodha, Pakjstan), Â Syed Zulfiqar Ali Shah

(International Islamic University, Islamabad, Pakistan), A Ahmad Raza Bilal (Supecior

University Lahore, Pakistan), A Ahmad Shekarchizadeh' (Islamic Republic of Iran), A Yulia

Hendri Yeni (Andalas University, Kampus Limąu Manis Padang), A Krzysztof Dziekonski (Bialystok University of Technology, Poland), A Hadi Jamshidi (Payame Noor Universsity,

Tehran, Iran), A Bandar (Khalaf) Âl-Harthi (Dar Al Uloom University, Saudi Arabia), A Ibrahim Danjuma (Modibbo Adama University of Technonology, Nigeria), Rafia Faiz (University of the

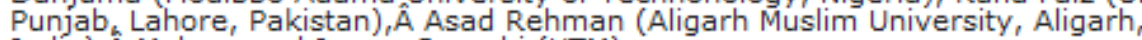
India), A Muhammad Imran Qureshi (UTM)

Published: $2015-12-12$

Science and Engineering

MODELLING OF HUMAN EXPERT DECISION MAKING IN RESERVOIR OPERATION

Wan Hussain Wan Ishak, Ku Ruhana Ku-Mahamud, Norita Md Nonwawi

圆 PDF

THE DEVELOPMENT OF WEB-BASED MANAGEMENT INFORMATION SYSTEM FOR THE CHILD MALNUTRITION SURVEILLANCE

Mera K. Delimayanti, Sigit Mulyono, Fajar T. Waluyanti

圆 PDF

INVESTIGATION OF COCONUT SHELLS ACTIVATED CARBON AS THE COST EFFECTIVE ABSORBENT IN DRINKING WATER FILTER

Suria Mohd Samdin, Lim Hooi Peng, Maryati Marzuki

圆 PDF

REDESIGNING EFFECT OF AUTO TAPING MACHINE SYSTEM IN SMALL PRODUCTION SCALE Didi Istardi, Remon Simatupang

国 PDF

OBJECT QUALITY ENHANCEMENT OF MULTI-FRAME LOW-RESOLUTION VIDEO Siti Aisyah, Fitri Arnia

圆 PDF

PERFORMANCE ANALYSIS FUZZY-PID VERSUS FUZZY FOR QUADCOPTER ALTITUDE LOCK SYSTEM Hendi Wicaksono, Yohanes Gunawan, Arbil Yodinata, Leonardie Leonardie

圆 PDF

THE EFFECT OF JAMMING ATTACK DETECTION AND MITIGATION ON ENERGY POWER CONSUMPTION (CASE STUDY IEEE 802.11 WIRELESS AD HOC NETWORK)

Nur Cahyono Kushardianto, Yudhi Kusnanto, Elvian Syafrurizal, Ahmad Hamim Tohari

圆 PDF 
SUSTAINABILITY: A NEW MANUFACTURING PARADIGM

Muhammad Imran Qureshi, Amran Md. Rasli, Ahmad Jusoh, Tan Owee Kowang

圆 PDF

ROLE OF ENTREPRENEURIAL LEADERSHIP AND COMMERCIALIZATION OF UNIVERSITY RESEARCH: A REVIEW Sri Gustina Pane, Dileep Kumar M

D PDF

MODELLING THE TRILOGY OF INNOVATION, LEARNING AND PERFORMANCE

Sri Gustina Pane, Dileep Kumar M, Muhammad Siddique

圆 PDF

GLOBAL POSITIONING SYSTEM AND GLOBAL SYSTEM FOR MOBILE COMMUNICATION MODEM APPLICATION AS CAR POSITION AND FUEL MONITORING SYSTEM

Masayu Anisah, Ahmad Taqwa, Amperawan Amperawan, Evelina Evelina, Sabilal Rasyad

圆 PDF

SYSTEM IDENTIFICATION OF CLAMPING FORCE CONTROLLER FOR SECONDARY PULLEY OF ELECTRO MECHANICAL DUAL ACTING PULLEY CONTINOUSLY VARIABLE TRANSMISSION (EMDAP CVT)

Mohd Azwarie Mat Dzahir, Mohamed Hussein, Bambang Supriyo, Kamarul Baharin Tawi, Sabri Che Kob, Mohd Azuwan Mat Dzahir

D PDF

IDENTIFICATION OF MOST SUITABLE BINARISATION METHODS FOR ACEHNESE ANCIENT MANUSCRIPTS RESTORATION SOFTWARE USER GUIDE

Fardian Fardian, Fitri Arnia, Sayed Muchallil, Khairul Munadi

圆 PDF

A REFERENCE-MODEL CONTROLLER TO MITIGATE THE EFFECT OF TIME DELAY CHANGE IN A NETWORKED CONTROL SYSTEMS

Rida Hudaya

圆 PDF

AUTOMATIC DEVELOPMENT OF FUZZY MEMBERSHIP FUNCTIONS ON HEPATITIS PATIENTS DATA USING PARTICLE SWARM OPTIMIZATION (PSO)

Candra Dewi, Ratna Putri P.S, Indriati Indriati

国 PDF

CALCULATION OF ROD FORCE OF THE TRUSS CONSTRUCTION

Saragih Darman F, Purba Marcedes, Winarno Bambang

圆 PDF

APPLICATION OF DISC SPRING IN CLAMPING FORCE MECHANISM FOR ELECTRO-MECHANICAL CONTINUOUSLY VARIABLE TRANSMISSION

Izhari Izmi Mazali, Kamarul Baharin Tawi, Bambang Supriyo, Mohd Sabri Che Kob, Nurulakmar Abu Husain, Mohd Salman Che Kob

圆 PDF

PERFORMANCE COMPARISON OF DENOISING METHODS FOR HISTORICAL DOCUMENTS

Sayed Muchallil, Fitri Arnia, Khairul Munadi, Fardian Fardian

D PDF

A CASE STUDY OF THE WEAKNESS OF FRESHMEN CHOSEN PASSWORD FOR ACADEMIC INFORMATION SYSTEM Ahmadiar Ahmadiar, Sayed Muchallil

圆 PDF 